\title{
Trends and Novel Approaches in Neoadjuvant Treatment of Breast Cancer
}

\author{
Guenther G. Steger ${ }^{a, b}$ Rupert Bartsch ${ }^{a, b}$ \\ aDepartment of Medicine I, Clinical Division of Oncology, Medical University of Vienna, \\ ${ }^{\mathrm{b} C}$ Comprehensive Cancer Centre Vienna, Austria
}

\section{Keywords}

Breast cancer - Chemotherapy - Neoadjuvant therapy . Targeted therapy

\section{Summary}

Breast cancer is the most prevalent malignant disease in women worldwide. Traditionally, surgical tumour resection was the primary step within the treatment algorithm of early stage disease; systemic therapy in order to reduce the rate of systemic recurrences followed. National Surgical Adjuvant Breast and Bowel Project (NSABP) trial B-18 found that pre- and postoperative administration of chemotherapy was equally effective. This study therefore established neoadjuvant chemotherapy as a valid treatment option, as the breast conservation rate is increased. Modern neoadjuvant regimens encompassing anthracyclines and taxanes yield pathological complete response $(p C R$ ) rates of around $20 \%$, with higher efficacy observed in triple-negative tumours. The antibody trastuzumab is the first targeted agent established in neoadjuvant regimens for the treatment of Her2-positive breast cancer, as it raised pCR rates up to $50 \%$. Novel approaches are aiming to increase the efficacy of neoadjuvant therapy. Inclusion of capecitabine might further increase $\mathrm{pCR}$ rates in selected patients, although data are not unanimous throughout the respective clinical trials. In patients harbouring BRCA-1 germline mutations, platinum derivatives are apparently promising. Novel Her2targeted agents such as lapatinib and pertuzumab are currently under investigation in several clinical trials, while the role of bevacizumab, a monoclonal antibody inhibiting angiogenesis, awaits future clarification.

\author{
Schlüsselwörter \\ Brustkrebs - Chemotherapie - Neoadjuvante Therapie . \\ Zielgerichtete Therapie
}

\section{Zusammenfassung}

Brustkrebs ist der häufigste bösartige Tumor bei Frauen. Traditionell stellt die Operation den ersten Behandlungsschritt dar, eine systemische Therapie wird meist danach verabreicht. Die Studie B-18 der NSABP (National Surgical Adjuvant Breast and Bowel Project) konnte nachweisen, dass kein Nachteil resultiert, wenn die systemische Therapie vor einer Operation verabreicht wird. Als Vorteil zeigte sich eine signifikant höhere Rate an brusterhaltenden Operationen. Moderne neoadjuvante Regime enthalten Anthrazykline und Taxane, wodurch ein pathologisch komplettes Ansprechen (pCR) bei etwa 20\% der Patientinnen erzielt wird. Bei tripel-negativen Tumoren wurde eine überlegene Wirksamkeit beobachtet. Mit pCR-Raten von bis zu $50 \%$ ist Trastuzumab, ein gegen den Her2-Rezeptor gerichteter monoklonaler Antikörper, die erste zielgerichtete Therapie, die Eingang in die neoadjuvante Behandlung Her2-positiver Tumore gefunden hat. Bei einem Teil der Patientinnen scheint eine Erweiterung der Chemotherapie um zusätzliche Zytostatika wie Capecitabin die pCR-Raten zu steigern, allerdings sind die diesbezüglichen Ergebnisse klinischer Studien nicht einhellig. Bei Frauen mit erblicher BRCA-1-Mutation könnten Platinderivate eine besondere Wirksamkeit aufweisen. Bei Her2-positiven Tumoren werden alternativ oder additiv zu Trastuzumab Substanzen wie Lapatinib und Pertuzumab in klinischen Studien getestet, bislang vorliegende Ergebnisse erscheinen vielversprechend. Die Rolle von Bevacizumab, einem Antikörper gegen den Gefäßwachstumsfaktor VEGF, im neoadjuvanten Setting ist unklar, und weitere Ergebnisse müssen abgewartet werden.

\section{KARGER \\ Fax +497614520714 \\ Information@Karger.de}

www.karger.com (c) 2011 S. Karger GmbH, Freiburg

$1661-3791 / 11 / 0066-0427 \$ 38.00 / 0$

Accessible online at:

www.karger.com/brc
Univ.-Prof. Dr. med. Günther G. Steger

Klinische Abteilung für Onkologie, Universitätsklinik für Innere Medizin Medizinische Universität Wien

Währinger Gürtel 18-20, 1090 Vienna, Austria

Tel. +43 1 40400-5459, Fax -6081

guenthersteger@meduniwien.ac.at 


\section{Introduction}

The term breast cancer as understood today summarizes a heterogeneous group of malignancies with major disparities in terms of prognosis and treatment response. The Stanford Group first established the classic 'intrinsic classification' of luminal, human epidermal growth factor receptor 2 (Her2)positive, normal-like, and basal-like cancers [1]. Herein, luminal is once more separated into luminal A - highly oestrogendependent and therefore oestrogen receptor- and progesterone receptor-positive with low grading and a low proliferation rate - and a less endocrine-responsive subtype called luminal B. The Her2-positive subtype describes highly consistent Her2-positive cancers as defined by immunohistochemistry or fluorescence-in-situ-hybridization (FISH). Basal-like breast cancers have a gene expression profile similar to the profile of myoepithelial cells of the basal epithelial layer of milk ducts [1]. Typically, those tumours are characterized by the lack of Her2 as well as hormone receptor (HR) expression; therefore, in the clinical routine setting, the term 'triple-negative tumour' is often used as surrogate for the basal-like subtype, with approximately $80 \%$ concordance [2]. While targeted treatment options are available for HR-positive and Her2positive tumours, chemotherapy remains the mainstay of treatment for triple-negative disease. It was recently suggested that so-called core basal-likes were related to tumours harbouring germline BRCA-1 mutations [3]. This, in terms, lead to the assumption that certain treatment strategies such as inhibitors of PARP-1 or platinum salts might prove fruitful in the treatment of triple-negative breast cancers [4].

\section{Breast Cancer and Neoadjuvant Therapy}

Starting in the 1970ies, preoperative systemic therapy was initially administered in cases of locally advanced inoperable breast cancer only [5]. Since those days, the concept of neoadjuvant treatment has evolved to become a standard in operable disease also, with the objective to increase the rate of breast conservation [6]. A milestone in this process was National Surgical Breast and Bowel Project (NSABP) trial B-18 which established equal efficacy of 4 cycles of doxorubicin plus cyclophosphamide, whether given before or after operation [7].

Over the last 30 years, a broad spectrum of different chemotherapeutic drugs has been studied in the neoadjuvant setting. Based upon those results, the respective consensus statements of the 2009 and 2011 St. Gallen Conferences state that neoadjuvant chemotherapy regimens should contain an anthracycline and a taxane $[8,9]$; as for the duration of neoadjuvant chemotherapy, it appears that the rate of pathological complete response (pCR) is significantly higher when more than 3-4 cycles of therapy are administered [10].
Recently, targeted therapies such as trastuzumab, a monoclonal antibody targeting Her2, were introduced. Other drugs targeting Her2, such as the antibody pertuzumab and the tyrosine kinase inhibitor lapatinib, are currently evaluated in clinical trials $[11,12]$. Bevacizumab, a monoclonal antibody binding the angiogenic growth factor VEGF (vascular endothelial growth factor), was also studied in clinical trials [13, 14], but its exact role in neoadjuvant treatment still remains elusive.

Besides the opportunity of increasing the rate of breast conservation, preoperative therapy offers the advantage of testing a tumour's chemosensitivity in vivo. On the downside, an increased rate of locoregional recurrences was suggested in a meta-analysis of neoadjuvant trials [15]. It is, however, important to remember that the mentioned meta-analysis included trials where operation was withheld in numerous patients of the respective neoadjuvant treatment groups. This assumption was strengthened by a positive test for interaction. Therefore, it is not proven that neoadjuvant treatment followed by optimal local therapy will increase the rate of locoregional recurrence.

\section{Endpoints of Neoadjuvant Therapy}

pCR, which indicates improved survival, is often regarded the most pertinent endpoint to assess the efficacy of neoadjuvant treatment [16-18]. Prognostic value of pCR was recently also established in Her2-positive disease [19]. Clearly, however, dichotomization of patients' response to neoadjuvant chemotherapy as pCR or no pCR is too simplistic. Prognosis of patients with residual disease still varies depending on the grade of response - from near pCR to complete resistance. Therefore, Symmans et al. [20] developed the residual cancer burden (RCB) score which incorporates pathologic measurements of primary tumour (size and cellularity) and nodal metastases (number and size). From today's view, the RCB score offers a meaningful alternative to $\mathrm{pCR}$ as primary endpoint in future trials of neoadjuvant chemotherapy.

\section{Chemotherapy}

\section{Platinum Derivatives}

Similar to tumours harbouring BRCA-1 germline mutations, core basal-like tumours apparently have deficient DNA repair pathways; it was therefore hypothesized that this subtype might be highly responsive to treatment with platinum salts. To test that assumption, trials were conducted in triple-negative tumours which encompass the majority of basal-like cancers. In metastatic breast cancer, progression-free survival in patients receiving platinum-based chemotherapy was significantly longer in the triple-negative group (6 vs. 4 months; 
$\mathrm{p}=0.05)$ [21]. In the preoperative setting, a pathologic complete remission rate of $62 \%$ (95\% confidence interval (CI) $50-73 \%$ ) was achieved with cisplatin/epirubicin/paclitaxel triplets in a population of 74 triple-negative patients [22]. The BALI-1 study, however, reported disappointing results: the response rate of first-line cisplatin in triple-negative tumours was $10 \%$, far less than anticipated [23]. This clearly demonstrates that triple-negative receptor status alone is insufficient to serve as response predictor.

In contrast to those findings, BRCA-1 germ-line mutations may in fact predict for response to neoadjuvant platinumbased chemotherapy. A small single-arm phase II study of single-agent cisplatin as neoadjuvant treatment for patients with BRCA-1-mutated breast cancer reported an unprecedented pCR rate of $90 \%$ [24]. On the other hand, BRCA-1mutated tumours were found to be relatively resistant to taxane-based chemotherapy [25]. Due to those intriguing data, randomized trials assessing the role of platinum salts in BRCA-1 carriers are warranted. While BRCA-1 mutations are rarely found in sporadic triple-negative cancers, BRCA-1 inactivation due to promoter methylation might occur in around $40 \%$ of patients [26]. This renders BRCA- 1 promoter methylation an interesting biomarker for prediction of response to neoadjuvant chemotherapy.

\section{Capecitabine}

Recently, 2 large randomized trials reported results with capecitabine in the neoadjuvant setting. ABCSG-24, a trial by the Austrian Breast and Colorectal Cancer Study Group (ABCSG), showed that the addition of capecitabine to a standard epirubicine and docetaxel regimen resulted in a significantly higher rate of pCR of 24 versus $16 \%(p=0.02)$ paralleled by an increased but manageable toxicity rate. A preplanned subgroup analysis of triple-negative tumours showed a very high pCR rate of $48 \%$ in the capecitabine arm as compared to only $13 \%$ in non-triple-negative tumours [27]. This is in good accordance with results of the Finnish adjuvant FinXX trial [28] in patients with moderate-to-high-risk early breast cancer where recurrence-free survival at 3 years followup was significantly better with the capecitabine regimen than in the standard control arm (93 vs. $89 \%$; hazard ratio (HR) 0.66 ; 95\% CI $0.47-0.94 ; \mathrm{p}=0.020$ ). In an explorative analysis of this study, the triple-negative subgroup especially profited from capecitabine in terms of recurrence-free survival with a HR of $0.43(p=0.024)$ [29]. In contrast, the German GeparQuattro trial did not show an altered pCR rate when capecitabine was added to neoadjuvant docetaxel [30]. These differences in study results may be explained by the fact that the trial designs differed significantly since ABCSG24 and the Finnish adjuvant trial administered 6 cycles of upfront capecitabine in a combination regimen, whereas in GeparQuattro only 4 cycles of capecitabine and docetaxel where given after an already highly effective anthracyclinecontaining induction therapy which also included cyclophosphamide. Moreover, triple-negative breast cancer appears to be a heterogenous subgroup in itself, which may also in part explain the differing study results. In summary, these results point to the fact that capecitabine may play a relevant role in the adjuvant and neoadjuvant treatment of breast cancer in general, and triple-negative tumours in particular [31]. To better define its role, further prospective evaluations are warranted.

\section{Targeted Therapy}

\section{Her2-Directed Targeted Therapy}

Her2 is a transmembrane receptor molecule of the Her family of human growth factor receptors. Her2 forms homo- or heterodimers with other proteins of the Her family; dimerization results in phosphorylation of tyrosine residues on the cytoplasmatic domain, which in terms activates downstream signalling pathways responsible for upregulation of cell proliferation, angiogenesis, and evasion of apoptosis [32].

Trastuzumab (rhMAb4D5) is a recombinant, humanized monoclonal antibody targeting the extra-cellular domain of Her2. Upon receptor binding, antibody-dependent cellular cytotoxicity and signalling inhibition causes cell degradation [33-35]. Trastuzumab is well established in palliative as well as adjuvant treatment of Her2-positive breast cancer. In the neoadjuvant setting, phase II studies incorporating trastuzumab reported pCR rates in the range of 18-39\% [36-38]. In a randomized study, Budzar et al. [39] treated patients with 4 cycles of paclitaxel followed by 4 cycles of FEC (fluorouracil, epirubicin, cyclophosphamide) with or without weekly trastuzumab for 24 weeks. After the inclusion of only 42 patients, a significant difference in terms of pCR rate in favour of trastuzumab was observed, and the trial was terminated ( 66.7 vs. $25 \% ; p=0.02$ ). Based upon those results, further studies were initiated. In 228 patients with locally advanced Her2-positive breast cancer treated with doxorubicin plus paclitaxel followed by paclitaxel and CMF (cyclophosphamide, methotrexate, fluorouracil) with or without trastuzumab, Gianni et al. [40] observed a pCR rate of $23 \%$ with chemotherapy alone; addition of trastuzumab increased this number to $43 \%(p=0.002)$. The GeparQuattro conducted by the German Breast Group finally established the incorporation of trastuzumab into neoadjuvant therapy of early breast cancer. 445 patients were randomly assigned to 4 cycles of EC (epirubicin, cyclophosphamide) followed by 4 cycles of docetaxel (+/- capecitabine) with or without trastuzumab. pCR rate (defined as no invasive or in situ residual tumours in the breast) was $31.7 \%$ in the trastuzumab group compared to $15.7 \%$ in the reference group. Importantly, the short-term cardiac toxicity profile was comparable between the 2 arms [41]. 
Novel approaches in the neoadjuvant therapy of Her2-positive disease include the incorporation of other Her2-targeted agents as well as chemotherapy-free biological treatment concepts. In the Her2-positive population of the GeparQuinto study, patients were randomized to $4 \times \mathrm{EC}$ followed by $4 \mathrm{cy}-$ cles of docetaxel in combination with trastuzumab or the tyrosine kinase inhibitor lapatinib. pCR rate, defined as no residual invasive tumour in the breast and the lymph nodes, was significantly higher in the trastuzumab arm (45 vs. 30\%), further strengthening the role of trastuzumab in the neoadjuvant setting [42].

The NeoAltto trial randomly assigned 450 patients with operable breast cancer to 18 weeks of neoadjuvant targeted therapy with lapatinib, trastuzumab, or the combination of both drugs; each arm also contained 12 administrations of weekly paclitaxel. pCR rate was significantly higher in the combination arm $(51.3 \%)$ compared to the respective single agent trastuzumab or lapatinib arms. Importantly, pCR rate was highest in HR-negative disease (61.3 vs. $41.6 \%$ ), in line with data of neoadjuvant chemotherapy in triple-negative tumours. Toxicity, however, was increased by the addition of lapatinib, and around $65 \%$ of patients in both lapatinibcontaining arms completed treatment as scheduled, compared to more than $90 \%$ in the trastuzumab group [11]. There is a strong biological rationale for the combination of trastuzumab and lapatinib, as lapatinib inhibits Her2 downregulation in response to antibody binding, thereby potentially increasing the efficacy of trastuzumab [43]. Still, as considerable toxicity was observed in the combination arm, and no established neoadjuvant regimen was used as chemotherapy backbone, a direct randomized comparison to the current standard of care is needed in order to fully assess the future role of lapatinib plus trastuzumab combinations in the neoadjuvant setting.

Finally, NeoSphere was a 4-arm phase II trial that randomly assigned patients to docetaxel plus trastuzumab, docetaxel plus pertuzumab, an alternative Her2-targeting antibody, and docetaxel plus the combination of both antibodies. A 4th arm consisted of trastuzumab and pertuzumab alone without a chemotherapy backbone. Total treatment duration was 12 weeks. While once again the triple-combination arm yielded highest pCR rates $(46 \%)$, this study was the first to report a clinically meaningful activity of a chemotherapy-free combination regimen in the neoadjuvant setting with a pCR rate of $17 \%$ [12]. Again, those results clearly emphasize that dual Her2 receptor blockade is promising. As with NeoAltto, however, direct comparison to regimens with standard duration and a standard chemotherapy backbone is necessary.

Trastuzumab-DM 1 (T-DM 1) is another promising option for the treatment of Her2-positive breast cancers; this antibody plus chemotherapy conjugate consists of trastuzumab and DM 1, a derivative of the anti-microtubule agent maytansine [44]. The compound has proven activity in Her2-positive metastatic breast cancer and is currently under investigation in a phase III clinical trial comparing T-DM 1 to trastuzumab plus docetaxel or paclitaxel (MARIANNE; NCT01120184). Due to its favourable toxicity profile, T-DM 1 is another attractive option in the neoadjuvant setting. Her2-targeted vaccination strategies, on the other hand, might be more useful as adjuvant therapy of breast cancer patients [45].

\section{VEGF-Directed Therapy}

VEGF was identified as the most important driving force behind malignant angiogenesis [46]. Inhibition of VEGF or the VEGF receptor therefore appeared to be a promising treatment approach. While somewhat disputed, the monoclonal antibody bevacizumab was the first VEGF-targeted drug incorporated into the therapy of breast cancer. In metastatic breast cancer, data of 5 clinical trials have become available. 4 of those were positive, the only negative study was conducted in heavily pretreated patients [47-51]. Based upon those results, studies were initiated evaluating the role of bevacizumab in early stage breast cancer. NSABP B-40 was a prospective randomized neoadjuvant phase III trial utilizing $4 \times$ AC (doxorubicin plus cyclophosphamide) followed by 4 cycles of docetaxel as chemotherapy backbone. The study asked 2 questions: First, will the addition of gemcitabine or capecitabine increase the efficacy of chemotherapy? Second, will the addition of bevacizumab yield additional benefit? While intensification of conventional chemotherapy did not improve pCR rates, a significantly higher pCR rate was observed in the bevacizumab arm (34.5 vs. $28.4 \%$; $\mathrm{p}=0.027)$. It is important to note that this benefit resulted solely from an increased pCR rate in HR-positive patients [14]. Results in the Her2-negative population of GeparQuinto, however, hint in the exact opposite direction. In the triple-negative subgroup, the addition of bevacizumab to standard chemotherapy yielded a significantly higher $\mathrm{pCR}$ rate, while no effect was observed in HR-positive patients [13]. Different sequencing of taxane and anthracyclines might be a potential reason; also, the duration of bevacizumab treatment differed between both studies. In general, however, the controversial results of NSABP B-40 and GeparTrio cannot be explained for now. Clearly, this once again highlights the urgent need to identify predictive markers for anti-angiogenic therapy in breast cancer.

ABCSG has recently started a randomized phase II study of a non-pegylated liposomale anthracycline in combination with docetaxel and trastuzumab with or without bevacizumab in Her2-positive patients (ABCSG-32, NCT01367028). There is a strong rationale for this combination, as Her2 signalling causes increased VEGF expression via the ras/raf/ MAPKinase pathway [52] due to an increase in HIF-1 $\alpha$ [53], a mechanism that may be blocked by trastuzumab. Indeed, Konecny et al. [54] suggested that the association between Her2 and VEGF expression points to VEGF as a relevant fac- 
tor in the aggressiveness of the Her2-positive phenotype, and therefore supports the use of combination therapies directed against both Her2 and VEGF.

Invasive lobular cancer appears to derive less benefit from neoadjuvant chemotherapy, and neoadjuvant endocrine therapy may be a reasonable option for selected patients $[6,55]$. Therefore, ABCSG-33 will evaluate the additive value of bevacizumab to neoadjuvant aromatase inhibitors in patients who are not candidates for neoadjuvant chemotherapy.

\section{Cancer Vaccines and Chemotherapy Schedules}

ABCSG-34 is the 3rd trial of ABCSG's new generation of neoadjuvant studies. ABCSG-34 asks the question whether the addition of the L-BLP25 liposome vaccine to neoadjuvant therapy improves upon the activity of conventional preoperative treatment of Her2-negative breast cancer patients. The vaccine has a synthetic lipopeptide sequence identical to a recurring sequence of the mucinous glycoprotein 1 (MUC-1) which is an integral cell membrane glycoprotein on the surface of epithelial cells [56]. In a phase IIb study, L-BLP25 demonstrated a survival benefit over best supportive care alone in patients with stage IIIB or IV non-small cell lung cancer (17.2 months vs. 13 months; HR 0.745 ; 95\% CI $0.533-$ 1.042 ) with the most pronounced effect seen in stage IIIB locoregional disease (HR 0.548; 95\% CI 0.301-0.999) [57]. According to tumour biology (estimated by receptor status, grading, and Ki67), patients will receive neoadjuvant chemotherapy or endocrine therapy and will be randomized to additional immunotherapy with L-BLP 25 or control. For the first time in neoadjuvant ABCSG trials, the RCB score is defined as primary study endpoint. A second randomization will be performed within the chemotherapy cohort: Patients will receive the conventional historical sequence of anthracyclines followed by docetaxel, or a reversed sequence starting with docetaxel. Indeed, 3 phase II trials suggested that a higher chemotherapy dose intensity is achieved when taxanes are administered first [58-60], which is an important aspect in light of the Norton-Simon hypothesis [61]. In the neoadjuvant setting, a single large randomized study observed a pCR rate of $20 \%$ with a reverse sequence design compared to $15 \%$ with the conventional sequence [62]. Furthermore, a retrospective analysis of 3,010 patients treated at the MD Anderson Cancer Center even reported a lower risk of relapse and death when paclitaxel was administered first [63].

\section{Conclusion}

Neoadjuvant chemotherapy today is a well established option in the treatment of patients with early stage breast cancer. Most modern regimens encompass anthracyclines and taxanes, often applied in a sequential design, with highest pCR rates observed in triple-negative disease; incorporation of further drugs such as capecitabine might further improve outcome in selected patients, although data are not unanimous. Platinum salts may be an effective alternative in patients harbouring BRCA-1 mutations, but data from phase III trials are still missing. Trastuzumab has evolved as mainstay for the preoperative treatment of Her2-positive patients, with pCR rates of approximately $50 \%$. Other targeted drugs such as lapatinib or pertuzumab have already shown promising results within clinical trials. Due to conflicting data, the exact role of bevacizumab awaits further clarification.

\section{Disclosure Statement}

G.S. received lecture fees from Roche, Amgen, SanofiAventis, and GlaxoSmithKline; R.B. declares no potential conflicts of interest.

\section{References}

$\checkmark 1$ Perou CM, Sørlie T, Eisen MB, van de Rijn M, Jeffrey SS, Rees CA, Pollack JR, Ross DT, Johnsen H, Akslen LA, Fluge O, Pergamenschikov A, Williams C, Zhu SX, Lønning PE, Børresen-Dale AL, Brown PO, Botstein D Molecular portraits of human breast cancer. Nature 2000;406:747-752.

-2 Sørlie T, Tibshirani R, Parker J, Hastie T, Marron JS, Nobel A, Deng S, Johnsen H, Pesich R, Geisler S, Demeter J, Perou CM, Lønning PE, Brown PO, Børresen-Dale AL, Botstein D: Repeated observation of breast tumor subtypes in independent gene expression data sets. Proc Natl Acad Sci U S A 2003; 100:8418-8423.

${ }_{3}$ Tischkowitz M, Brunet JS, Bégin LR, Huntsman DG, Cheang MC, Akslen LA, Nielsen TO, Foulkes WD: Use of immunohistochemistry can refine prognosis in triple negative breast cancer. BMC Cancer 2007;7:134.
4 Bartsch R, Ziebermayr R, Zielinski CC, Steger GG: Triple-negative breast cancer. Wien Med Wochenschr 2010;160:174-181.

5 Buzdar AU: Preoperative chemotherapy treatment of breast cancer - a review. Cancer 2007;110:23942407.

6 Kaufmann M, von Minckwitz G, Bear HD, Buzdar A, McGale P, Bonnefoi H, Colleoni M, Denkert C, Eiermann W, Jackesz R, Makris A, Miller W, Pierga JY, Semiglazov V, Schneeweiss A, Souchon R, Stearns V, Untch M, Loibl S: Recommendations from an international expert panel on the issue of neoadjuvant (primary) systemic treatment of operable breast cancer: new perspectives 2006. Ann Oncol 2007;18:1927-1934.

7 Fisher B, Brown A, Mamounas E, Wieand S, Robidoux A, Margolese RG, Cruz AB Jr, Fisher ER, Wickerham DL, Wolmark N, DeCillis A, Hoehn JL, Lees AW, Dimitrov NV: Effect of preoperative chemotherapy on loco-regional disease in women with operable breast cancer: findings from National Surgical Adjuvant Breast and Bowel Project B-18. J Clin Oncol 1997;15:2483-2493.
8 Goldhirsch A, Ingle JN, Gelber RD, Coates AS, Thuerlimann B, Senn H-J, and Panel members: Thresholds for therapies: highlights of the St Gallen International Expert Consensus on the Primary Therapy of Early Breast Cancer 2009. Ann Oncol 2009;20:1319-1329.

9 Goldhirsch A, Wood WC, Coates AS, Gelber RD, Thuerlimann B, Senn H-J, and Panel members. Strategies for subtypes - dealing with the diversity of breast cancer: highlights of the St Gallen International Expert Consensus on the Primary Therapy of Early Breast Cancer 2011. Ann Oncol 2001;22:1736-1747.

10 Steger GG, Galid A, Gnant M, Mlineritsch B, Lang A, Tausch C, Rudas M, Greil R, Wenzel C, Singer CF, Haid A, Poestelberger S, Samonigg H, Luschin-Ebengreuth G, Kwasny W, Klug E, Kubista E, Menzel C, Jakesz R: Pathologic complete response with six compared with three cycles of neoadjuvant epirubicin plus docetaxel and granulocyte colony-stimulating factor in operable breast cancer: results of ABCSG - 14. J Clin Oncol 2007;25:2012-2018. 
11 Baselga J, Bradbury I, Eidtmann H, Di Cosimo S, Aura C, De Azambuja E, Gomez H, Dinh P, Fauria K, Van Dooren V, Paoletti P, Goldhirsch A, Chang T-W, Lang I, Untch M, Gelber RD, PiccartGebhart M, on Behalf of the NeoALTTO Study Team: First results of the NeoALTTO trial (BIG 01-06 / EGF 106903): a phase III, randomized, open label, neoadjuvant study of lapatinib, trastuzumab, and their combination plus paclitaxel in women with HER2-positive primary breast cancer. Cancer Res 2010;70(suppl 24):abst S3-3.

12 Gianni L, Pienkowski T, ImY-H, Roman L, Tseng L-M, Liu M-C, Lluch-Hernandez A, Semiglazov V, Szado T, Ross G: Neoadjuvant pertuzumab (P) and trastuzumab $(\mathrm{H})$ : antitumor and safety analysis of a randomized phase II study (NeoSphere). Cancer Res 2010;70(suppl 24):abst S3-2.

13 Gerber H, Eidtmann H, Rezai M, Fasching PA, Tesch H, Eggemann H, Schrader I, Kittel K, Hanusch CA, Kreienberg R, Solbach C, Jackisch C, Kunz G, Blohmer JU, Huober JB, Hauschild M, Loibl S, Nekljudova V, Untch M, von Minckwitz G GBG/AGO study groups: Neoadjuvant bevacizumab and anthracycline-taxane-based chemotherapy in 686 triple-negative primary breast cancers: secondary endpoint analysis of the GeparQuinto study (GBG 44). J Clin Oncol 2011;29(suppl 15):abst 1006.

14 Bear HD, Tang G, Rastogi P, Geyer CE, Robidoux A, Atkins JN, Baez L, Brufsky A Mehta RS, Fehrenbacher L, Pajon ER, Senecal FM, Gaur R, Margolese RG, Adams PT, Gross HM, Swain SM, Mamounas EP, Costantino JP, Wolmark N: The effect on pCR of bevacizumab and/or antimetabolites added to standard neoadjuvant chemotherapy: NSABP protocol B-40. J Clin Oncol 2011;29(suppl 15):LBA1005.

15 Mauri D, Pavlidis N, Ioannidis JP: Neoadjuvant versus adjuvant systemic treatment in breast cancer: a meta-analysis. J Natl Cancer Inst 2005; 97:188-194.

-16 Bear HD, Anderson S, Smith RE, Geyer CE Jr, Mamounas EP, Fisher B, Brown AM, Robidoux A Margolese R, Kahlenberg MS, Paik S, Soran A, Wickerham DL, Wolmark N: Sequential preoperative or postoperative docetaxel added to preoperative doxorubicin plus cyclophosphamide for operable breast cancer: National Surgical Breast and Bowel Project B-27. J Clin Oncol 2006;24:20192027.

17 Kuerer HM, Newman LA, Smith TL, Ames FC, Hunt KK, Dhingra K, Theriault RL, Singh G, Binkley SM, Sneige N, Buchholz TA, Ross MI, McNeese MD, Buzdar AU, Hortobagyi GN, Singletary SE: Clinical course of breast cancer patients with complete pathologic primary tumor and axillary lymph node response to doxorubicinbased neoadjuvant chemotherapy. J Clin Oncol 1999;17:460-469.

18 Wolmark N, Wang J, Mamounas E, Bryant J, Fisher B: Preoperative chemotherapy in patients with operable breast cancer: 9-year results from National Surgical Breast and Bowel Project B-18. J Natl Cancer Inst 2001;30:96-102.

19 Untch M, Fasching PA, Konecny GE, Hasmüller S, Lebeau A, Kreienberg R, Camara O, Müller V, du Bois A, Kühn T, Stickeler E, Harbeck N, Höss C, Kahlert S, Beck T, Fett W, Mehta KM, von Minckwitz G, Loibl S: Pathologic complete response after neoadjuvant chemotherapy plus trastuzumab predicts favorable survival in human epidermal growth factor receptor 2-overexpressing breast cancer: results from the TECHNO Trial of the AGO and GBG Study Groups. J Clin Oncol 2011;29:3351-3357.
20 Symmans WF, Peintinger F, Hatzis C, Rajan R, Kuerer H, Valero V, Assad L, Poniecka A, Hennessy B, Green M, Buzdar AU, Singletary SE, Hortobagyi GN, Pusztai L: Measurement of residual breast cancer burden to predict survival after neoadjuvant chemotherapy. J Clin Oncol 2007; 25:4414-4422.

21 Sirohi B, Arnedos M, Popat S, Ashley S, Nerurkar A, Walsh G, Johnston S, Smith IE: Platinum-based chemotherapy in triple-negative breast cancer. Ann Oncol 2009;19:1847-1852.

22 Frasci G, Comella P, Rinaldo M, Iodice G, Di Bonito M, D'Aiuto M, Petrillo A, Lastoria S, Siani C, Comella G, D'Aiuto G: Preoperative weekly cisplatin-epirubicin-paclitaxel with G-CSF support in triple-negative operable breast cancer. Ann Oncol 2009;20:1185-1192.

23 Baselga J, Gomez P, Awada A, Greil R, Braga S, Climent M, Wardley A, Zubel A, Groos J, Kaufman B: The addition of cetuximab to cisplatin increases overall response rate (ORR) and progression-free survival (PFS) in metastatic triplenegative breast cancer (TNBC): results of a randomized phase II study (BALI-1). Presented at the 35th European Society of Medical Oncology Congress 2010, abst 274O.

24 Byrski T, Huzarski T, Dent R, Gronwald J, Zuziak D, Cybulski C, Kladny J, Gorski B, Lubinski J, Narod SA: Response to neoadjuvant therapy with cisplatin in BRCA1-positive breast cancer patients. Breast Cancer Res Treat 2009;115:359-363.

25 Seynaeve C, Jager A, Hooning M, Jager A, Hooning $\mathrm{M}$, Van Deurzen $\mathrm{CH}$, Bontenbal $\mathrm{M}$, Blom J, Collee M, van den Ouweland A, Kriege M: Activity of taxane chemotherapy for metastatic breast cancer (MBC) in BRCA1 and BRCA2 mutation carriers compared to sporadic $\mathrm{BC}$ patients. J Clin Oncol 2010;28(suppl 15):abst 1020.

26 Birgisdottir V, Stefansson OA, Bodvarsdottir SK, Hilmarsdottir H, Jonasson JG, Eyfjord JE: Epigenetic silencing and deletion of the BRCA1 gene in sporadic breast cancer. Breast Cancer Res 2006;8:R38.

27 Steger GG, Greil R, Jakesz R, Lang A, Mlineritsch B, Rudas M, Marth C, Stoeger H, Singer CF, Gnant $\mathrm{M}$, and the Austrian Breast and Colorectal Cancer Study Group (ABCSG): ABCSG-24: efficacy of anthracycline- and taxanebased neoadjuvant therapy \pm capecitabine (C) in triple-negative early breast cancer (TNBC). Ann Oncol 2010;21:79.

28 Joensuu H, Kellokumpu-Lehtinen P-L, Huovinen R, Jukkola-Vuorinen A, Tanner M, Asola R, Kokko R, Ahlgren J, Auvinen P, Hemminki A, Paija O, Helle L, Nuortio L, Villman K, Nilsson G, Lahtela S-L, Lehtiö K, Pajunen M, Poikonen P, Nyandoto P, Kataja V, Bono P, Leinonen M, Lindman H, on behalf of the FinXX-Study Investigators: Adjuvant capecitabine in combination with docetaxel and cyclophosphamide plus epirubicin for breast cancer: an open-label, randomised controlled trial. Lancet Oncol 2009;10:1145-1151.

29 Joensuu H, Kellokumpu-Lehtinen P, Huovinen R, Jukkola-Vuorinen A, Tanner M, Kokko R, Ahlgren J, Bono P, Auvinen P, Lindman H: Integration of capecitabine $(\mathrm{X})$ into adjuvant therapy comprising docetaxel (T) followed by 5-FU, epirubicin, and cyclophosphamide (CEF): efficacy in patients with triple-negative breast cancer (BC). J Clin Oncol 2010;28(suppl 15):abst 531.
30 Von Minckwitz G, Rezai M, Loibl S, Fasching PA, Huober J, Tesch H, Bauerfeind I, Hilfrich J, Eidtmann H, Gerber B, Hanusch C, Kühn T, du Bois A, Blohmer JU, Thomssen C, Dan Costa S, Jackisch C, Kaufmann M, Mehta K, Untch M: Capecitabine in addition to anthracycline- and taxane-based neoadjuvant treatment in patients with primary breast cancer: phase III GeparQuattro study. J Clin Oncol 2010;28:2015-2023.

31 Steger GG, Barrios C, O'Shaughnessy J, Martin M, Gnant $\mathrm{M}$ : Capecitabine for triple-negative breast cancer: review of available data. Breast 2011;20(suppl 1):P307.

32 Nahta R, Yu D, Hung MC, Hortobagyi GN, Esteva FJ: Mechanisms of disease: understanding resistance to Her2-targeted therapy in human breast cancer. Nat Clin Pract Oncol 2006;3:269280.

33 Cooley S, Burns LJ, Repka T, Miller JS: Natural killer cell cytotoxicity of breast cancer targets is enhanced by two distinct mechanisms of antibody dependent cellular cytotoxicity against LFA-3 and HER2/neu. Exp Hematol 1999;27:1533-1541.

34 Gennari R, Menard S, Fagnoni F, Ponchio L, Scelsi M, Tagliabue E, Castiglioni F, Villani L, Magalotti C, Gibelli N, Oliviero B, Ballardini B, Da Prada G, Zambelli A, Costa A: Pilot study of the mechanism of action of preoperative trastuzumab in patients with primary operable breast tumors overexpressing HER2. Clin Cancer Res 2004;10:5650-5655.

35 Clynes RA, Towers TL, Presta LG, Ravetch JV: Inhibitory $\mathrm{Fc}$ receptors modulate in vivo cytotoxicity against tumor targets. Nat Med 2006;6:443-446.

36 Burstein HJ, Harris LN, Gelman R, Lester SC, Nunes RA, Kaelin CM, Parker LM, Ellisen LW, Kuter I, Gadd MA, Christian RL, Kennedy PR, Borges VF, Bunnell CA, Younger J, Smith BL, Winer EP: Preoperative therapy with trastuzumab and paclitaxel followed by sequential adjuvant doxorubicin/cyclophosphamide for HER2 overexpressing stage II or III breast cancer: a pilot study. J Clin Oncol 2003;21:46-53.

37 Wenzel C, Hussian D, Bartsch R, Pluschnig U, Locker GJ, Rudas M, Gnant MF, Jakesz R, Zielinkski CC, Steger GG: Preoperative therapy with epidoxorubicin and docetaxel plus trastuzumab in patients with primary breast cancer: a pilot study. J Cancer Res Clin Oncol 2004;130:400-404.

38 Hurley J, Doliny P, Reis I, Silva O, GomezFernandez C, Velez P, Pauletti G, Powell JE, Pegram MD, Slamon DJ: Docetaxel, cisplatin, and trastuzumab as primary systemic therapy for human epidermal growth factor receptor 2-positive locally advanced breast cancer. J Clin Oncol 2006;24:1831-1838.

39 Buzdar AU, Ibrahim NK, Francis D, Booser DJ, Thomas ES, Theriault RL, Pusztai L, Green MC, Arun BK, Giordano SH, Cristofanilli M, Frye DK, Smith TL, Hunt KK, Singletary SE, Sahin AA, Ewer MS, Buchholz TA, Berry D, Hortobagyi GN: Significantly higher pathologic complete remission rate after neoadjuvant therapy with trastuzumab, paclitaxel, and epirubicin chemotherapy: results of a randomized trial in human epidermal growth factor receptor 2-positive operable breast cancer. J Clin Oncol 2005;23:3676-3685.

40 Gianni L, Semiglazov V, Manikhas GM, Eiermann W, Lluch A, Tjulandin S, Feyereislova A, Vanhauwere B, Valagussa P, Baselga J: Neoadjuvant trastuzumab in locally advanced breast cancer (NOAH): antitumour and safety analysis. J Clin Oncol 2007; 25(suppl 18):abst 532. 
41 Untch M, Rezai M, Loibl S, Fasching PA, Huober J, Tesch H, Bauerfeind I, Hilfrich J, Eidtmann H, Gerber B, Hanusch C, Kühn T, du Bois A, Blohmer JU, Thomssen C, Dan Costa S, Jackisch C, Kaufmann M, Mehta K, von Minckwitz G: Neoadjuvant treatment with trastuzumab in HER2-positive breast cancer: results from the GeparQuattro study. J Clin Oncol 2010;28:20242031.

42 Untch M, Loibl S, Bischoff J, Eidtmann H, Kaufmann M, Blohmer J-U, Hilfrich J, Strumberg D, Fasching PA, Kreienberg R, Tesch H, Hanusch C, Gerber B, Rezai M, Jackisch C, Huober J, Kuehn T, Nekljudova V, von Minckwitz G: Lapatinib vs. trastuzumab in combination with neoadjuvant anthracyclinetaxane-based chemotherapy: primary efficacy endpoint analysis of the GEPARQUINTO STUDY (GBG 44). Cancer Res 2010;70(suppl):81S.

43 Scaltriti M, Verma C, Guzman M, Jimenez J, Parra JL, Pedersen K, Smith DJ, Landolfi S, Ramon y Cajal S, Arribas J, Baselga J: Lapatinib, a HER2 tyrosine kinase inhibitor, induces stabilization and accumulation of HER2 and potentiates trastuzumab-dependent cell cytotoxicity. Oncogene 2009;28:803-814.

44 LoRusso PM, Weiss D, Guardino E, Girish S, Sliwkowski MX: Trastuzumab emtansine: a unique antibody-drug conjugate in development for human epidermal growth factor receptor 2-positive cancer. Clin Cancer Res 2011;17:6437-6447.

45 Mittendorf EA, Clifton GT, Holmes JP, Clive KS, Patil R, Benavides LC, Gates JD, Sears AK, Stojadinovic A, Ponniah S, Peoples GE: Clinical trial results of the HER-2/neu (E75) vaccine to prevent breast cancer recurrence in high-risk patients: from US Military Cancer Institute Clinical Trials Group Study I-01 and I-02. Cancer 2011;Epub ahead of print.

46 Folkman J, Klagsbrun M: Angiogenic factors. Science 1987;235:442-447.

47 Miller KD, Chap LI, Holmes FA, Cobleigh MA Marcom PK, Fehrenbacher L, Dickler M, Overmoyer BA, Reimann JD, Sing AP, Langmuir V, Rugo HS: Randomized phase III tria of capecitabine compared with bevacizumab and capecitabine in patients with previously treated metastatic breast cancer. J Clin Oncol 2005;23:792799.

48 Miller K, Wang M, Gralow J, Dickler M, Cobleigh M, Perez EA, Shenkier T, Cella D, Davidson NE: Paclitaxel plus bevacizumab versus paclitaxel alone for metastatic breast cancer. N Engl J Med 2007;357:2666-2676.
49 Miles D, Chan A, Romieu G, Dirix LY, Cortés J, Pivot X, Tomczak P, Delozier T, Sohn JH, Provencher L, Puglisi F, Harbeck N, Steger GG, Schneeweiss A, Wardley AM, Chlistalla A, Romieu G: Phase III study of bevacizumab plus docetaxel compared with placebo plus docetaxel for the first-line treatment of human epidermal growth factor receptor 2-negative metastatic breast cancer. J Clin Oncol 2010;28:3239-3247.

50 Robert NJ, Diéras V, Glaspy J, Brufsky AM, Bondarenko I, Lipatov ON, Perez EA, Yardley DA, Chan SY, Zhou X, Phan SC, O'Shaughnessy J: RIBBON-1: randomized, double-blind, placebocontrolled, phase III trial of chemotherapy with or without bevacizumab for first-line treatment of human epidermal growth factor receptor 2-negative, locally recurrent or metastatic breast cancer. J Clin Oncol 2011;29:1252-1260.

51 Brufsky A, Valero V, Tiangco B, Dakhil SR, Brize A, Bousfoul N, Rugo HS, Yardley DA: Impact of bevacizumab (BEV) on efficacy of second-line chemotherapy (CT) for triple-negative breast cancer (TNBC): analysis of RIBBON-2. J Clin Oncol 2011;29(suppl):abst 1010.

52 Yen L, You XL, Al Moustafa AE, Batist G, Hynes NE, Mader S, Meloche S, Alaoui-Jamali MA: Heregulin selectively upregulates vascular endothelial growth factor secretion in cancer cell and stimulates angiogenesis. Oncogene 2000;19:34603469.

53 Laughner E, Taghavi P, Chiles K, Mahon PC, Semenza GL: HER2 (neu) signaling increases the rate hypoxia-induceable factor $1 \alpha$ (HIF-1 $\alpha)$ synthesis: novel mechanism for HIF-1-mediated vascular endothelial growth factor expression. Mol Cell Biol 2001;21:3995-4004

54 Konecny GE, Meng YG, Untch M, Wang HJ, Bauerfeind I, Epstein M, Stieber P, Vernes JM, Gutierrez J, Hong K, Beryt M, Hepp H, Slamon DJ, Pegram MD: Association between HER-2/neu and vascular endothelial growth factor expression predicts clinical outcome in primary breast cancer patients. Clin Cancer Res 2004;10:1706-1716.

55 Wenzel C, Bartsch R, Hussian D, Pluschnig U, Altorjai G, Zielinski CC, Lang A, Haid A, Jakesz R, Gnant M, Steger GG: Invasive ductal carcinoma and invasive lobular carcinoma of breast differ in response following neoadjuvant therapy with epidoxorubicin and docetaxel + G-CSF. Breast Cancer Res Treat 2007;104:109-114.

56 Butts C, Murray N, Maksymiuk A, Goss G, Marshall E, Soulières D, Cormier Y, Ellis P, Price A, Sawhney R, Davis M, Mansi J, Smith C, Vergidis D, Ellis P, MacNeil M, Palmer M: Randomized phase IIB trial of BLP25 liposome vaccine in stage IIIB and IV non-small-cell lung cancer. J Clin Oncol 2005;23:6674-6681.
77 Butts C, Maksymiuk A, Goss G, Soulières D, Marshall E, Cormier Y, Ellis PM, Price A Sawhney R, Beier F, Falk M, Murray N: Updated survival analysis in patients with stage IIIB or IV non-small-cell lung cancer receiving BLP25 liposome vaccine (L-BLP25): phase IIB randomized, multicenter, open-label trial. J Cancer Res Clin Oncol 2011;137:1337-1342.

58 Piedbois S, Serin D, Priou F, Laplaige P, Greget S, Angellier E, Teissier E, Berdah JF, Fabbro M, Valenza B, Herait P, Jehl V, Buyse M: Dosedense adjuvant chemotherapy in node-positive breast cancer: docetaxel followed by epirubicin cyclophosphamide (T/EC) or the reverse sequence $(\mathrm{EC} / \mathrm{T})$, every two weeks, versus docetaxel, epirubicin and cyclophosphamide (TEC) every three weeks. AERO B03 randomized phase II study. Ann Oncol 2007;18:52-57.

59 Puhalla S, Mrozek E, Young D, Ottman S, McVey A, Kendra K, Merriman NJ, Knapp M Patel T, Thompson ME, Maher JF, Moore TD, Shapiro CL: Randomized phase II adjuvant trial of dose-dense docetaxel before or after doxorubicin plus cyclophosphamide in axillary node-positive breast cancer. J Clin Oncol 2008;26:1691-1697.

60 Wildiers H, Dirix L, Neven P, Prové A, Clement P, Squifflet P, Amant F, Skacel T, Paridaens R: Delivery of adjuvant sequential dose-dense FEC-Doc to patients with breast cancer is feasible, but dose reductions and toxicity are dependent on treatment sequence. Breast Cancer Res Treat 2009;114:103112.

61 Simon R, Norton L: The Norton-Simon hypothesis: designing more effective and less toxic chemotherapy regimens. Nat Clin Pract Oncol 2006;3:406407.

62 Earl HM, Vallier A, Hiller L, Fenwick N, Iddawela M, Hughes-Davies L, Provenzano E, McAdam K, Hickish T, Caldas C, for NeotAnGo Investigators: Neo-Tango: a neoadjuvant randomized phase III trial of epirubicin/cyclophosphamide and paclitaxel + /- gemcitabine in the treatment of women with high-risk early breast cancer (EBC): first report of the primary endpoint, pathological complete response (pCR). J Clin Oncol 2009;27(suppl 15):abst 522.

63 Alvarez RH, Bianchini G, Hsu L, Cristofanilli M, Esteva FJ, Pusztai L, Buzdar A, Hortobagyi GN Valero V: The effect of different sequencing regimens of taxanes and anthracyclines in the primary systemic treatment (PST) of breast cancer (BC) patients (pts): M. D. Anderson Cancer Center retrospective analysis. J Clin Oncol 2010;28(suppl 15):abst 548. 